\title{
ゲーブルトップ紙容器種によるチルドグレープ紅茶飲料の 香気透過性の相違
}

\author{
秋山正行 ${ }^{1 *}$, 片倉友義 ${ }^{1}$, 渡邊武俊 ${ }^{2}$, 今吉有理子 ${ }^{2}$, 池田三知男 ${ }^{1}$, \\ 市橋信夫 ${ }^{1}$, 大西正展 ${ }^{2}$, 岩渕久克 ${ }^{2}$ \\ 1 森永乳業(株) 食品総合研究所 \\ 2 三栄源エフ・エフ・アイ(株)
}

\section{Permeability of Volatile Compounds from Chilled Grape-flavored Black Tea Beverage through Packaging Materials of Gable-top Cartons}

\author{
Masayuki Akiyama ${ }^{1 *}$, Tomoyoshi Katakura ${ }^{1}$, Taketoshi Watanabe'2 Yuriko Imayoshi², \\ Michio Ikeda ${ }^{1}$, Nobuo Ichihashi ${ }^{1}$, Masanobu Onishi ${ }^{2}$ and Hisakatsu Iwabuchi \\ ${ }^{1}$ Food Research \& Development Institute, Morinaga Milk Industry Co., Ltd., 5-1-83, Higashihara, Zama, Kanagawa $252-8583$ \\ ${ }^{2}$ San-Ei Gen F.F.I., Inc., 1-1-11, Sanwa-cho, Toyonaka, Osaka 561-8588
}

\begin{abstract}
Volatile compounds from a chilled grape-flavored black tea beverage (grape tea) permeating through gable-top non-barrier and barrier cartons were analyzed by gas chromatography/mass spectrometry (GC/MS) and $\mathrm{GC} /$ olfactometry $(\mathrm{GC} / \mathrm{O})$. We first developed a new glass apparatus to capture volatile compounds permeating through packaging materials of gable-top cartons. Using this apparatus, the sampling conditions for volatile compounds from grape tea permeating through the non-barrier and barrier materials were determined as follows: SPME fiber, PDMS/DVB; sampling temperature, $10^{\circ} \mathrm{C}$; duration of SPME exposure, $30 \mathrm{~min}$; sampling timing for SPME exposure, after $24-\mathrm{hr}$ incubation at $10^{\circ} \mathrm{C}$. Under the conditions, volatile compounds from grape tea permeating through the non-barrier and barrier materials were captured by the SPME fibers, and analyzed by GC/MS. The GC/MS results showed remarkable differences in the peak areas of ester compounds depending on the packaging materials. In addition, $\mathrm{GC} / \mathrm{O}$ analyses revealed that odor intensities (charm values) of the following six odorants: ethyl 2-methylpropanoate, ethyl butanoate, ethyl 2-methylbutanoate, ethyl 3-methylbutanoate, ethyl 2methylpentanoate, and methyl anthranilate, were significantly higher when packed in the non-barrier material than when packed in the barrier material. These results will provide useful information for development of formulas and selection of packaging materials suitable for gable-top carton beverages.
\end{abstract}

(Received Sep. 1, 2011; Accepted Oct. 25, 2011)

Keywords : gable-top carton, grape, black tea, chilled beverage, volatile compound キーワード: ゲーブルトップ紙容器, グレープ, 紅茶, チルド飲料, 香気成分

チルド紅茶飲料は, $10^{\circ} \mathrm{C}$ 以下の冷蔵温度帯で製造, 流通, 販売される商品である。チルド紅茶飲料の種類には, スト レートティーやミルクティーの他に，レモンやピーチ，グ レープ等の果汁や香料を配合した様々なフルーツフレー バード紅茶飲料がある.

チルド紅茶飲料の容器としては，牛乳容器として馴染み のあるゲーブルトップ型のポリエチレン加工紙容器（ゲー ブルトップ紙容器）が多く用いられている。紅茶飲料用に は, 包材層構成の異なるノンバリア (NB) 容器とガスバリ ア（B）容器がある，通常は，容器コストを考慮し NB容器

${ }^{1} \mathbf{T} 252-8583$ 神奈川県座間市東原 5-1-83

2 个561-8588 大阪府豊中市三和町 1-1-11

*連絡先 (Corresponding author), m_akiyam@morinagamilk.co.jp
が使用されることが多いが，フルーツフレーバード紅茶飲 料のようなフルーツや香料由来の香気強度が強い場合, あ るいはその特性によってガスバリア性のある B 容器が使 用される。B容器の使用により，香気散逸による保存中の 品質低下や, 容器外部からの酸素や異臭侵入等を防止する ことができるため，商品品質の保持向上が期待できる，仮 に, NB 容器の内容物香気の多くが容器外部へ透過した場 合，店舗に陳列されている間等に他商品へ香気成分が移行 し（この現象を，以後「移り香」と記す），消費者クレーム に繋がることがある。

現状，製品開発上における容器種の選定は，簡易的な香 気移行テストの官能評価結果を踏まえ, 開発者が製品の香 調や香気強度を経験に基づいて総合的に判断し，使用する 
包材の種類を選定する場合が多く，客観性のある選定指標 の設定が難しい，それ故，製品の開発設計時に，香気成分 の容器透過性を定量的に計測し, 容器種（材質）を合理的 に選定できる手法の開発が望まれている。

本研究では，チルドフレーバード紅茶飲料を代表するグ レープティーについて, 紙容器を透過する香気を捕集する 実験系（装置, 条件）を確立し, 移り香の主原因となる透 過香気成分を明らかにした。これによりグレープティーの 容器種の合理的な選定手法の確立が期待される。さらに, 他種のゲーブルトップ紙容器飲料への同分析手法の適用も 可能と考えられる.

\section{実 験 方 法}

\section{1. グレープティーと容器包材}

移り香の懸念から，バリアタイプの容器を用いているグ レープティーを実験対象とした。グレープティーの原材料 には, 砂糖混合果糖ぶどう糖液糖, (赤) ぶどう果汁（アメ リカ産), 紅茶 (スリランカ産), 香料, 酸味料, 甘味料を 用いた。 その調製は, 紅茶葉から $60^{\circ} \mathrm{C}$ の温湯にて浸漬抽出 した紅茶抽出液 (Brix 約 $1.5^{\circ}$, 約 $58^{\circ} \mathrm{C}$ ) を, チルド飲料の 流通温度である $10^{\circ} \mathrm{C}$ 以下に冷却し, 各種原料を混合・溶解 した後, $90^{\circ} \mathrm{C} \cdot 10$ 分間でバッチ殺菌し, $10^{\circ} \mathrm{C}$ 以下に冷却し た.グレープティーの特性值は, 果汁 $5 \%$, Brix 7.6 , pH 3.3 であった。実験試料は, 各種実験の都度, 同ロット原 料・同処方により，研究室にて調製した。

ゲーブルトップ紙容器は, 日本紙パック株式会社 (東京) 製のポリエチレン加工紙ノンバリア $(\mathrm{NB})$ タイプのラミ ネート原紙と, バリア $(\mathrm{B})$ タイプのラミネート原紙の 2 種 類を用いた。 それぞれの原紙の層構成は, 以下の通りで あった。

$\mathrm{NB}$ ：(内）無添加 LDPE $40.5 \mu \mathrm{m} /$ 原紙 $325.5 \mathrm{~g} / \mathrm{m}^{2}$ ／ 無添加 LDPE $17.3 \mu \mathrm{m}$ （外）

$\mathrm{B}$ ：（内）無添加 $\mathrm{LDPE} /$ 接着強化 $\mathrm{PE} / \mathrm{EVOH} /$ 原紙 $320.0 \mathrm{~g} / \mathrm{m}^{2} /$ 無添加 LDPE $23.8 \mu \mathrm{m}$ （外）

ここで, LDPEは低密度ポリエチレン, EVOH はエチレ ンビニルアルコール共重合樹脂である。また，下線層の厚 さは $59.4 \mu \mathrm{m}$ である.

\section{SPME ファイバー種の選択}

グレープティーの香気成分捕集に適した SPME ファイ バー種を選定するために, 以下の 4 種類のファイバー, Polydimethylsiloxane/Divinylbenzene (PDMS/DVB), Divinylbenzene/Carboxen/Polydimethylsiloxane (DVB/CAR/PDMS), Carboxen/Polydimethylsiloxane (CAR/PDMS), Polydimethylsiloxane (PDMS)(Sigma-Aldrich Co., St. Louis, Mo., U.S.A.) を用いて，次の手順にて選定した。

まず，グレープティー $10 \mathrm{~g}$ を $40 \mathrm{~mL}$ 容のガラス製バイ アルに充填後, 密封し, $10^{\circ} \mathrm{C} て ゙ 30$ 分間静置平衡化した後, 極性の異なる上記 4 種類の SPME ファイバーを露出する
ことにより， $10^{\circ} \mathrm{C}$ で 30 分間香気成分を捕集し, GC/MS 分 析を行った。

同時に，グレープティー中の香気成分（量）について確 認し，ファイバー種選択および透過香気モデル作成の参考 とするために，以下の溶媒抽出法による GC/MS 分析を 行った。すなわち，試料溶液 $200 \mathrm{~g}$ に内部標準物質として 3-heptanol を $50 \mu \mathrm{g}$ 添加後, ジクロロメタン $200 \mathrm{~mL}$ を用 いて抽出し, 有機層を $0.5 \mathrm{~mL}$ まで濃縮後, GC/MS 分析を 行った。

\section{3. 透過香気成分の捕集装置}

図 1 に示すガラス製の香気捕集容器は, 既報文献1) 3) を 参考に作製した。実際に使用する際には，ガラス容器の間 に容器包材を挟んでクランプで固定し，片側にグレープ ティーを満量 $\left(\right.$ 約 $\left.236 \mathrm{~cm}^{3}\right)$ 注入して, $10^{\circ} \mathrm{C}$ で一定時間静置 した後，中央に挟んだ包材を経由して対合部に透過した香 気を SPME ファイバーにより捕集した。内部の試料溶液 が容器包材に接触する面積は, 約 $79 \mathrm{~cm}^{2}$ であった.

\section{SPME ファイバーによる香気成分の捕集時間}

透過香気捕集装置における SPME ファイバーによる香 気捕集時間を設定するために，グレープティーを捕集装置 に封入して $10^{\circ} \mathrm{C} て ゙ 24$ 時間静置した後, 10〜50 分間, SPME ファイバーを露出することにより，2 種の容器包材 (NB ま たは B）の透過香気成分を捕集し，GC/MS 分析を行った。

\section{5. 香気捕集までの静置時間}

透過香気の捕集容器にグレープティーを封入してから 1〜8 日間静置した後の透過香気成分について, 30 分間, SPME ファイバーを露出することにより，2 種の容器包材 （NB またはB）の透過香気成分を捕集し, GC/MS 分析を 行った.

\section{6. $\mathrm{GC} / \mathrm{MS}$ 分析}

GC/MS 分析は, 質量検出器 5975B とガスクロマトグラ フ 6890N (Agilent Technologies, Palo Alto, CA, U.S.A.) を 結合させた装置を使用して 3 回行った。分離カラムは, DB-WAX $(60 \mathrm{~m} \times 0.25 \mathrm{~mm}$, 膜厚 $0.25 \mu \mathrm{m}$, Agilent Technologies）を用いた。 キャリアガスにはへリウムガスを用い, 最適な線速度が得られるようにするために, カラム流量を $1.6 \mathrm{~mL} / \mathrm{min}$ に設定した. カラム温度のプログラムは, $50^{\circ} \mathrm{C}$

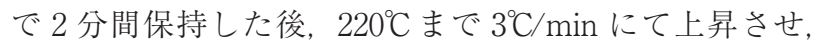
$220^{\circ} \mathrm{C}$ にて保持した. SPMEにより捕集した香気の注入 は, 注入口（内径 $0.75 \mathrm{~mm}$ インサート管) (Sigma-Aldrich Co.) を $250^{\circ} \mathrm{C}$ に維持し, スプリットレスモードにて行った. 溶媒抽出物の注入は, 注入口（内径 $4.0 \mathrm{~mm}$ 不活性化処理 済インサート, Agilent Technologies）を $250^{\circ} \mathrm{C}$ に維持し, $5 \mu \mathrm{L}$ をスプリット比 10：1にて行った. GC/MS 分析は, データの定量比較が必要な場合には, 同じ測定条件の下で 行った。

\section{7. $\mathrm{GC} / \mathrm{O}$ 分析}

GC/O (CharmAnalysis ${ }^{\mathrm{TM}}$ ) は, DATU, Inc. (Geneva, NY, 


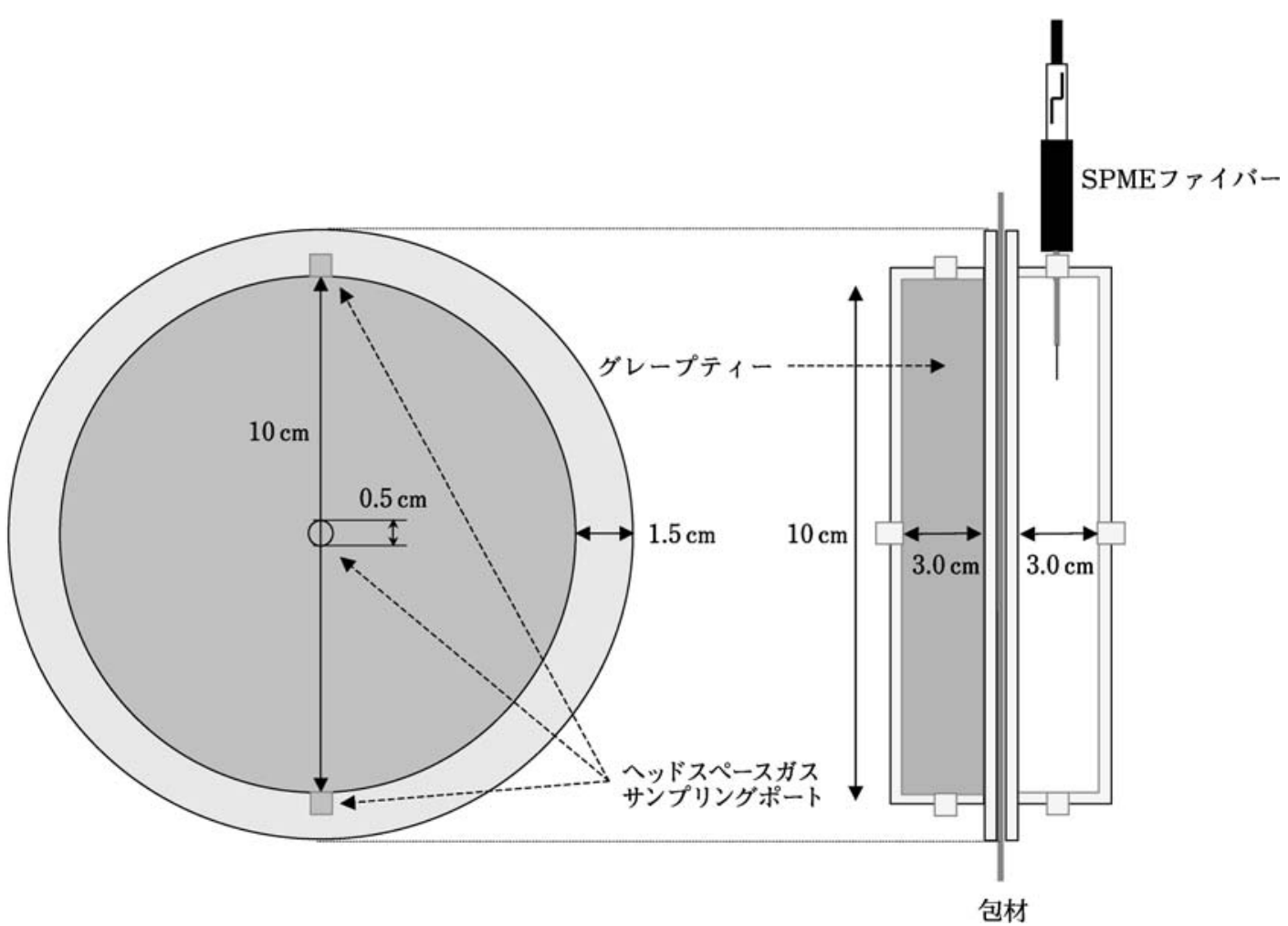

図 1 容器包材の透過香気成分のガラス製捕集装置

U.S.A.）により改良されたガスクロマトグラフ 6890 (Agilent Technologies) の装置)を使用して 3 回行った。 分離カラムには, DB-WAX $(15 \mathrm{~m} \times 0.32 \mathrm{~mm}$, 膜厚 $0.25 \mu \mathrm{m}$, Agilent Technologies）を用いた。キャリアガスにはへリ ウムガスを用い，最適な線速度が得られるようにするため に，カラム流量を $3.2 \mathrm{~mL} / \mathrm{min}$ に設定した。 カラム温度の プログラムは, 初期温度 $40^{\circ} \mathrm{C}$, 以降 $230^{\circ} \mathrm{C}$ まで $6^{\circ} \mathrm{C} / \mathrm{min} に$ て上昇させ， $230^{\circ} \mathrm{C} に て$ 保持した。注入口および検出器の 温度は, $225^{\circ} \mathrm{C}$ と $230^{\circ} \mathrm{C}$ した。 また GC インジェクション パージは，開始 1 分間はオフとした。なお，GCに注入す る香気成分量は, GC インジェクターによるスプリット比 を変化させることで順次 3 倍ずつ希釈し，9 倍希釈時まで 分析した516.

デー夕の取込み，および解析は，CharmAnalysis ${ }^{\text {TM装置 }}$ に付属のコンピューターに内蔵されている Charmware ver. 1.12 (DATU, Inc.) 点有いて行った。すなわち, CharmAnalysis ${ }^{\mathrm{TM}}$ 中， スニッファーは，オルファクトメー ターから出てくるエアの匂いを嗅ぎ，何かの匂いを感知し ている間，マウスボタンを押し続け，その後感知した香調 を, 予め設定した香調 (匂い特性) 集の中から選択するこ とにより, コンピューターに，その匂い特性，保持時間， 感知している時間の長さを記録した，GC 注入サンプルの 順次希釈により得られた，チャームクロマトグラムの各匂 い成分の面積值を次式により求め, チャームバリュー（匂 い強度）として記録した。
Charm value $=\int_{\text {peak }} \mathrm{F}^{\mathrm{n}-1} \mathrm{di} \quad\left(\right.$ 式 ${ }^{4)}$

$\mathrm{F}$, dilution factor (希䆏倍率);

$\mathrm{n}$, number of dilution (希棌回数);

di, Ri end - Ri begin (保持時間).

各々の它い成分の保持時間は, $\mathrm{C}_{6}-\mathrm{C}_{28} n$-alkanes（東京化 成工業(株)，東京）を用いて保持指標（Kovats indices）に変 換した。

\section{8. 香気成分の同定}

香気成分の同定のために使用した市販の標準物質は，東 京化成工業(株) および Sigma-Aldrich Co.から購入した。 検出された香気成分と，標準物質が同一であることの確認 は，香気成分のマススペクトルと保持指標が，それぞれ標 準物質のマススペクトルおよび保持指標と同一である事を もってした。

\section{実験結果および考察}

\section{1. ゲーブルトップ紙容器包材の透過香気成分の捕集条件}

(1) SPME ファイバー種

グレープティーの香気成分捕集に適した SPME ファイ バー種を選定するために，4 種類の SPME ファイバー (PDMS/DVB, DVB/CAR/PDMS, CAR/PDMS, PDMS) を 使用して，バイアル中に密閉したグレープティーのヘッド スペースから香気成分を捕集し，GC/MS 分析を行った。 そのトータルイオンクロマトグラムを図 2 に示した。 


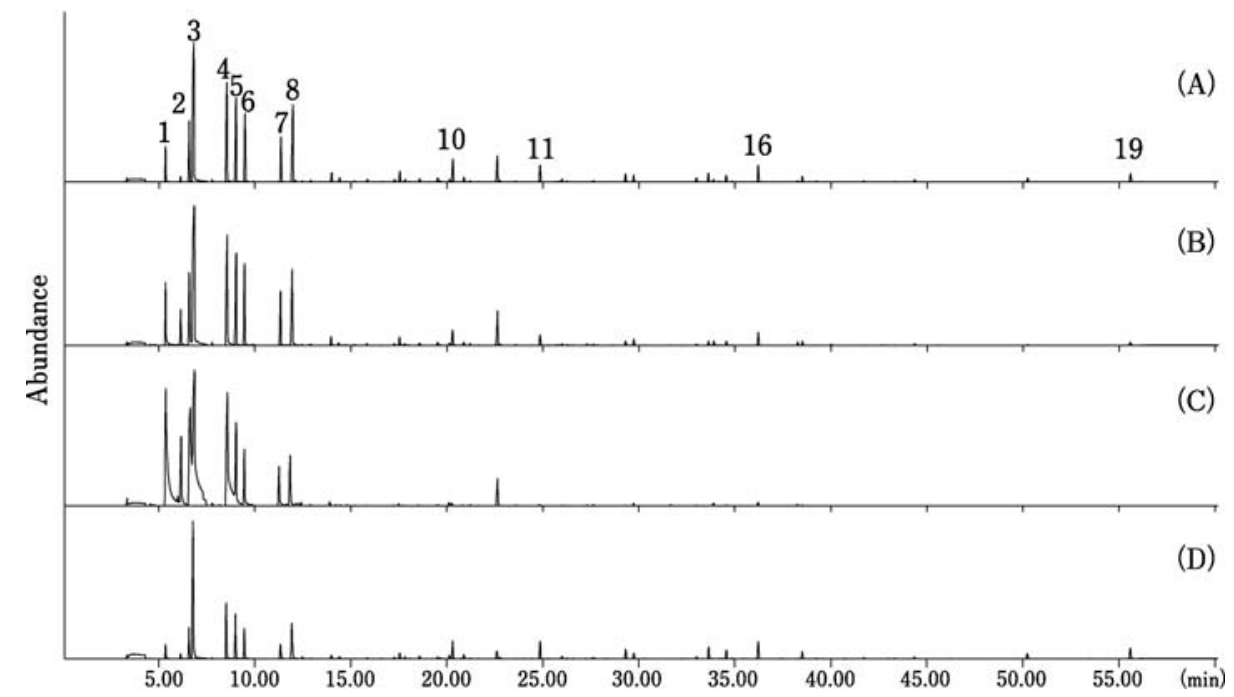

図 2 各種 SPME ファイバー捕集によるグレープティー香気成分のトータルイオンクロマトグラム比較 (A), PDMS/DVB ; (B), DVB/CAR/PDMS ; (C), CAR/PDMS ; (D), PDMS. 図中の数字は, 表 $1 \cdot 2$ の化合物 No. に対応する.

PDMS（図 2-D）は他種のファイバーと比較して全体的 に捕集香気量が少なく, CAR/PDMS（図 2-C）では後半の 比較的揮発性の低い成分はほとんど検出されなかった。 PDMS/DVB（図 2-A）とDVB/CAR/PDMS（図 2-B）の ファイバーはどちらも全体的にバランスよく香気成分を捕 集していたが, 後半部分に検出される styrallyl acetate（図 2-16）や一般的にグレープの特徵香とされている methyl anthranilate (図 2-19) 等の成分は, PDMS/DVBの方に多 く捕集される傾向が観られた。一方で，溶媒抽出による香 気成分として, 後半部分にも多くの成分が検出されること を確認した（データ不掲載）.

以上より，本研究では，PDMS/DVBをグレープティー の香気捕集用ファイバーとして選定した.

(2) SPME ファイバーによる香気捕集時間

グレープティーを捕集装置内にて 24 時間静置した後, NB またはB の容器包材を透過した香気成分を, SPME ファ イバーの露出時間を変えて捕集した。透過・捕集した主要 19 成分のトータルピーク面積の結果を, 表 1 に示した.

Bの容器包材を透過した香気成分は, NB 包材のものと 比較して香気量が明らかに少なく, 30 分以降にしか検出さ れない成分も観られたが，10〜50 分の間ほぼ線形的に増加 した。一方, $\mathrm{NB}$ 包材を透過した香気の捕集量は全ての成 分で B 包材使用時よりも多く, ethyl 2-methylpropanoate (表1-No.3) のように40 分以降では増加しない成分も観ら れた。

以上より，捕集量の線形性が比較的保たれており，2 種 類の容器包材でより多くの香気成分を捕集できる 30 分間 を本実験系での香気捕集時間として設定した。

(3) 香気捕集までの静置時間

前項まで, グレープティーを透過香気捕集装置に封入し,
24 時間静置後に容器包材の透過香気成分の捕集を開始し ていたが，改めて装置へ試料を封入してから香気捕集する までの静置時間について検討した。

グレープティーの商品が, 実際に，店頭で販売されてい る日数は, 流通事情から製造後 1 週間程度までと考えられ る.そこで，グレープティーを封入してから 1〜8 日後の 透過香気について, GC/MSで分析した。

図 3 の横軸は $10^{\circ} \mathrm{C}$ で静置した日数, 縦軸は主要な 19 成 分 (ethyl acetate, ethyl propanoate, ethyl 2-methylpropanoate, ethyl butanoate, ethyl 2-methylbutanoate, ethyl 3methylbutanoate, 3-methylbutanyl acetate, ethyl 2-methylpentanoate, ethyl heptanoate, ethyl octanoate, ethyl decanoate, citronellyl acetate, styrallyl acetate, methyl cinnamate, methyl anthranilate, limonene, linalool, acetophenone, phenethyl alcohol) の GC/MS 分析によるトータ ルピーク面積值を示す. 静置後 1 日で NB 包材は B 包材 の 10 倍以上の透過香気成分量が検出され, その後, 徐々に 増加し， 5〜 6 日後に総香気量が平衡に達した。

このことから, 紙容器の香気透過性の違いについては, 1 日静置後の透過香気を比較することで十分に考察できる と考えられた。また，商品が店頭に陳列される頃にはNB 包材からの透過香気量はかなり多いことが推察された。

これまでの検討から透過香気成分の捕集条件として, SPME ファイバー種をPDMS/DVB，捕集時間を 30 分間, 捕集タイミングを包材設置・グレープティー封入後, 24 時 間静置後とした。

\section{2. 容器包材種による透過香気成分}

(1) GC/MS 分析による香気成分の比較

容器包材種（NB，B）による透過香気成分を比較するた めに, 前節 1 (ゲーブルトップ紙容器包材の透過香気成分 
表 $1 \mathrm{SPME}$ ファイバーの捕集時間による

\begin{tabular}{|c|c|c|c|c|c|c|c|c|c|c|c|}
\hline \multirow[b]{4}{*}{ No. } & \multirow[b]{4}{*}{ 化合物名 } & & & & & & & & & \multicolumn{2}{|c|}{ ピーク面積値 } \\
\hline & & \multicolumn{10}{|c|}{ バリア } \\
\hline & & \multicolumn{2}{|c|}{10 分 } & \multicolumn{2}{|c|}{20 分 } & \multicolumn{2}{|c|}{30 分 } & \multicolumn{2}{|c|}{40 分 } & \multicolumn{2}{|c|}{50 分 } \\
\hline & & mean & $\overline{\operatorname{RSD}(\%)^{b}}$ & mean & RSD (\%) & mean & RSD (\%) & mean & $\overline{R S D}(\%)$ & mean & RSD (\%) \\
\hline 1 & ethyl acetate & 33 & 5.8 & 31 & 5.8 & 33 & 5.8 & 35 & 5.8 & 28 & 5.8 \\
\hline 2 & ethyl propanoate & 113 & 7.1 & 153 & 7.1 & 168 & 7.1 & 189 & 7.1 & 190 & 7.1 \\
\hline 3 & ethyl 2-methylpropanoate & 358 & 12.5 & 508 & 12.5 & 607 & 12.5 & 709 & 12.5 & 789 & 12.5 \\
\hline 4 & ethyl butanoate & 142 & 9.9 & 221 & 9.9 & 280 & 9.9 & 333 & 9.9 & 396 & 9.9 \\
\hline 5 & ethyl 2-methylbutanoate & 44 & 9.6 & 71 & 9.6 & 95 & 9.6 & 106 & 9.6 & 125 & 9.6 \\
\hline 6 & ethyl 3-methylbutanoate & 31 & 9.6 & 52 & 9.6 & 67 & 9.6 & 81 & 9.6 & 94 & 9.6 \\
\hline 7 & 3-methylbutanyl acetate & 12 & 5.8 & 20 & 5.8 & 27 & 5.8 & 30 & 5.8 & 36 & 5.8 \\
\hline 8 & ethyl 2-methylpentanoate & 33 & 9.2 & 56 & 9.2 & 78 & 9.2 & 98 & 9.2 & 117 & 9.2 \\
\hline 9 & limonene & 60 & 6.1 & 107 & 6.1 & 159 & 6.1 & 195 & 6.1 & 261 & 6.1 \\
\hline 10 & ethyl heptanoate & 6 & 9.8 & 13 & 9.8 & 21 & 9.8 & 27 & 9.8 & 35 & 9.8 \\
\hline 11 & ethyl octanoate & $\mathrm{ND}^{c}$ & & ND & & 10 & 9.8 & 17 & 5.8 & 25 & 5.8 \\
\hline 12 & linalool & ND & & ND & & $\mathrm{ND}$ & & $\mathrm{ND}$ & & ND & \\
\hline 13 & ethyl decanoate & ND & & ND & & $\mathrm{ND}$ & & $\mathrm{ND}$ & & ND & \\
\hline 14 & acetophenone & ND & & ND & & $\mathrm{ND}$ & & 4 & 5.8 & 5 & 5.8 \\
\hline 15 & citronellyl acetate & ND & & ND & & $\mathrm{ND}$ & & ND & & ND & \\
\hline 16 & styrallyl acetate & ND & & ND & & 5 & 9.8 & 6 & 5.8 & 9 & 5.8 \\
\hline 17 & phenethyl alcohol & ND & & ND & & $\mathrm{ND}$ & & $\mathrm{ND}$ & & ND & \\
\hline 18 & methyl cinnamate & ND & & ND & & $\mathrm{ND}$ & & $\mathrm{ND}$ & & ND & \\
\hline 19 & methyl anthranilate & ND & & ND & & $\mathrm{ND}$ & & $\mathrm{ND}$ & & ND & \\
\hline
\end{tabular}

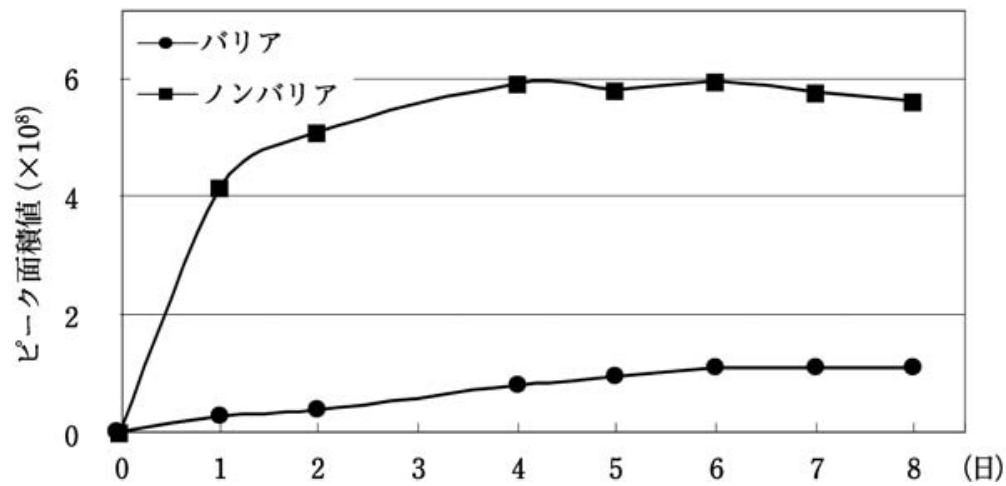

図 3 グレープティー包材透過香気の主要 19 成分 ${ }^{a}$ のトータルピーク面積值の経時変化

${ }^{a}$ ethyl acetate, ethyl propanoate, ethyl 2-methylpropanoate, ethyl butanoate, ethyl 2-methylbutanoate, ethyl 3methylbutanoate, 3-methylbutanyl acetate, ethyl 2-methylpentanoate, ethyl heptanoate, ethyl octanoate, ethyl decanoate, citronellyl acetate, styrallyl acetate, methyl cinnamate, methyl anthranilate, limonene, linalool, acetophenone, phenethyl alcohol

の捕集条件）にて設定した捕集条件下において，SPME ファイバーを用いて各包材の透過香気成分を捕集し, GC/MS 分析を行った.

表 2 は，主要香気成分のピーク面積值を示している。表 中に示した透過成分比は，NBに対するB 包材の透過香気 成分のピーク面積割合 (\%)を示す。主要な透過香気成分は, ethyl 2-methylpropanoate (表 2-No. 3) や ethyl butanoate （表 2-No. 4）などの揮発性の高いエステル類であった。B
包材における，これらのエステル類の透過香気量は，NB 包材に対していずれも約 3〜9\%と少なく, B 包材はこれら の成分に対して高いバリア性を示した。

一方, EVOH フィルムの limonene 透過速度は, LDPE フィルムに比べて非常に小さく, バリア性に優れているこ とが報告されている ${ }^{8)}$. しかし，今回のグレープティーの透 過香気分析において, limonene の透過成分比は, NB 包材 比で約 50\%であり，B 包材においてエステル類よりも高い 


\begin{tabular}{|c|c|c|c|c|c|c|c|c|c|}
\hline \multicolumn{10}{|c|}{$\left(\times 10^{4}\right)^{a}$} \\
\hline \multicolumn{10}{|c|}{ ノンバリア } \\
\hline \multicolumn{2}{|c|}{10 分 } & \multicolumn{2}{|c|}{20 分 } & \multicolumn{2}{|c|}{30 分 } & \multicolumn{2}{|c|}{40 分 } & \multicolumn{2}{|c|}{50 分 } \\
\hline mean & RSD (\%) & mean & RSD (\%) & mean & RSD (\%) & mean & RSD (\%) & mean & RSD (\%) \\
\hline 746 & 5.7 & 580 & 5.8 & 551 & 3.2 & 572 & 4.8 & 504 & 4.6 \\
\hline 4659 & 1.9 & 4717 & 0.9 & 4541 & 3.1 & 4422 & 2.4 & 3906 & 3.7 \\
\hline 12396 & 3.6 & 13876 & 0.3 & 14102 & 3.4 & 14110 & 2.4 & 13047 & 3.1 \\
\hline 7582 & 6.4 & 9475 & 1.7 & 10945 & 6.6 & 11489 & 4.5 & 10946 & 4.9 \\
\hline 2323 & 9.9 & 3153 & 3.5 & 4004 & 9.1 & 4459 & 7.8 & 4390 & 7.6 \\
\hline 1917 & 7.6 & 2697 & 3.8 & 3477 & 9.4 & 3895 & 8.2 & 3883 & 7.1 \\
\hline 635 & 8.9 & 945 & 4.5 & 1281 & 10.0 & 1515 & 8.8 & 1589 & 7.9 \\
\hline 1798 & 9.9 & 2773 & 3.8 & 3878 & 10.0 & 4804 & 8.3 & 5163 & 8.3 \\
\hline 113 & 9.9 & 180 & 10.0 & 267 & 9.3 & 385 & 7.9 & 394 & 10.0 \\
\hline 480 & 9.8 & 850 & 3.5 & 1284 & 8.0 & 1688 & 8.6 & 1956 & 3.2 \\
\hline 157 & 10.0 & 304 & 3.6 & 465 & 5.2 & 674 & 8.7 & 781 & 4.2 \\
\hline $\mathrm{ND}$ & & 8 & 4.1 & 13 & 5.5 & 19 & 6.5 & 23 & 5.1 \\
\hline ND & & 6 & 9.1 & 10 & 6.9 & 17 & 9.6 & 23 & 9.7 \\
\hline 6 & 9.5 & 11 & 2.9 & 16 & 7.4 & 21 & 4.3 & 27 & 3.4 \\
\hline 11 & 9.7 & 29 & 6.2 & 49 & 4.6 & 75 & 9.5 & 94 & 9.9 \\
\hline 148 & 9.2 & 281 & 4.2 & 427 & 8.8 & 573 & 8.7 & 673 & 4.4 \\
\hline $\mathrm{ND}$ & & $\mathrm{ND}$ & & ND & & $\mathrm{ND}$ & & $\operatorname{trace}^{d}$ & \\
\hline 35 & 9.9 & 70 & 0.7 & 107 & 3.3 & 158 & 8.7 & 196 & 3.7 \\
\hline 35 & 8.0 & 71 & 3.4 & 107 & 5.4 & 153 & 7.8 & 191 & 2.7 \\
\hline
\end{tabular}

比率で透過することが示された。この結果は, EVOH 層を 含む HDPE (高密度ポリエチレン) 多層フィルムにおいて, limonene の透過係数が ethyl butanoateよりも大きいこ と帛から示唆された。

このように，グレープティーの香気においては，揮発性 の高いエステル類の香気成分が $\mathrm{NB}$ 包材において多く透過 するが，それらはB 包材において 10\%未満にまで透過が 抑えられていることが明らかとなった。

(2) $\mathrm{GC} / \mathrm{O}$ 分析による匂い成分の比較

前項（2-(1)）において, 各容器包材を透過する香気の成 分量を比較した。しかし, 香気成分量が必ずしも匂いの強 さと相関しないため，実際に匂いとして感知され，移り香 の原因となりうる成分を見出すために, GC/O 分析を行っ た。表 3 は, SPMEファイバーで捕集した透過香気の $\mathrm{GC} / \mathrm{O}$ 分析結果である.

$B$ 包材では 12 の匂い成分を感知した。一方, NB 包材では 15 成分が感知されており，Bでは感知されなかった green 香 ((Z)-3-hexenol) や sweet 香 ( $(E)$-beta-damascenone) が 確認された，9倍希釈時には，B 包材では感知できる匂い 成分がなかったのに対し, NB 包材では 6 成分 (ethyl 2methylpropanoate, ethyl butanoate, ethyl 2-methylbutanoate, ethyl 3-methylbutanoate, ethyl 2-methylpentanoate, methyl anthranilate) が感知された.

これらの包材種間で匂い強度に顕著な差が認められた 6
成分のうち, methyl anthranilate は紫のブドウ感に, ethyl 2-methylpropanoate, ethyl butanoate 等の他 5 成分はグ レープのフルーティーな朼として寄与していた。これら は，グレープやワインに特徵的な香気成分として報告され

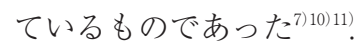

また，グレープティーの溶媒抽出による GC/MS 分析か ら得られた，これら 6 成分の含量を基に調製したモデル溶 液 (香料) の香りを官能にて確認したところ, NB 包材から 漏れてくるグレープ様の香りと同様な香調であった。

\section{要約}

(1) ゲーブルトップ紙容器の透過香気成分を捕集するガ ラス製装置を作製した。

(2) グレープティーの透過香気成分の捕集条件を検討し た結果, SPMEファイバー種: PDMS/DVB, 捕集温度： $10^{\circ} \mathrm{C}$, 捕集時間: 30 分間, 捕集タイミング : 24 時間静置後, に設定した。

(3) ノンバリアとバリア容器種間で，香気成分量に差が 認められるグレープティーの透過香気成分を明らかにし た．特にエステル類において差が顕著であった。

(4) 容器種間で透過香気の匂い強度が顕著に異なる, 6 種の㫐い成分 (ethyl 2-methylpentanoate, ethyl butanoate, ethyl 2-methylbutanoate, ethyl 3-methylbutanoate, ethyl 2methylpentanoate, methyl anthranilate) を明らかにした。 
表 2 容器包材種によるグレープティーの透過香気成分量比較

\begin{tabular}{|c|c|c|c|c|c|c|}
\hline \multirow[b]{3}{*}{ No. } & \multirow[b]{3}{*}{ 化合物名 } & \multicolumn{4}{|c|}{ "ピーク面積值 $\left(\times 10^{4}\right)^{a}$} & \multirow{3}{*}{$\begin{array}{l}\text { 透過成分比 } \\
\text { B/NB (\%) }\end{array}$} \\
\hline & & \multicolumn{2}{|c|}{ バリア（B） } & \multicolumn{2}{|c|}{ ノンバリア（NB） } & \\
\hline & & mean & $\mathrm{RSD}(\%)^{b}$ & mean & $\overline{R S D}(\%)$ & \\
\hline 1 & ethyl acetate & 69 & 4.2 & 813 & 3.7 & 9 \\
\hline 2 & ethyl propanoate & 378 & 3.3 & 6465 & 1.5 & 6 \\
\hline 3 & ethyl 2-methylpropanoate & 1276 & 3.9 & 19852 & 1.4 & 6 \\
\hline 4 & ethyl butanoate & 581 & 3.0 & 14967 & 1.4 & 4 \\
\hline 5 & ethyl 2-methylbutanoate & 182 & 3.8 & 5405 & 2.9 & 3 \\
\hline 6 & ethyl 3-methylbutanoate & 143 & 3.1 & 4886 & 3.1 & 3 \\
\hline 7 & 3-methylbutanyl acetate & 50 & 1.0 & 1783 & 4.7 & 3 \\
\hline 8 & ethyl 2-methylpentanoate & 158 & 5.6 & 5428 & 8.5 & 3 \\
\hline 9 & limonene & 250 & 8.3 & 474 & 10.9 & 53 \\
\hline 10 & ethyl heptanoate & 56 & 7.4 & 1714 & 9.7 & 3 \\
\hline 11 & ethyl octanoate & 19 & 5.8 & 674 & 14.9 & 3 \\
\hline 12 & linalool & $\mathrm{ND}^{c}$ & & 22 & 7.1 & \\
\hline 13 & ethyl decanoate & ND & & 21 & 10.0 & \\
\hline 14 & acetophenone & $\operatorname{trace}^{d}$ & & 26 & 8.8 & \\
\hline 15 & citronellyl acetate & ND & & 78 & 11.9 & \\
\hline 16 & styrallyl acetate & 20 & 9.4 & 512 & 12.4 & 4 \\
\hline 17 & phenethyl alcohol & ND & & 5 & 7.5 & \\
\hline 18 & methyl cinnamate & ND & & 132 & 9.2 & \\
\hline \multirow[t]{2}{*}{19} & methyl anthranilate & ND & & 177 & 16.5 & \\
\hline & Total & 2821 & 3.0 & 57349 & 2.8 & 5 \\
\hline
\end{tabular}

${ }^{a}$ ピーク面積值：3 回試行による測定平均值.

${ }^{b}$ RSD: relative standard deviation.

${ }^{c} \mathrm{ND}$ : not detected.

${ }^{d}$ trace: $\mathrm{S} / \mathrm{N}<5$.

表 3 容器包材種によるグレープティーの透過香気 $\mathrm{GC} / \mathrm{O}$ 分析

\begin{tabular}{|c|c|c|c|c|}
\hline \multirow[b]{2}{*}{ 保持指標 } & \multirow[b]{2}{*}{ 化合物名 } & \multirow[b]{2}{*}{ 匂い特性 } & \multicolumn{2}{|c|}{ charm value $^{a}$} \\
\hline & & & バリア & ノンバリア \\
\hline 979 & ethyl 2-methylpropanoate & fruity & $36 \pm 4.4$ & $160 \pm 25$ \\
\hline 1030 & ethyl butanoate & fruity & $11 \pm 6.4$ & $88 \pm 20$ \\
\hline 1046 & ethyl 2-methylbutanoate & fruity & $21 \pm 8.1$ & $180 \pm 23$ \\
\hline 1063 & ethyl 3-methylbutanoate & fruity & $6.0 \pm 6.7$ & $110 \pm 12$ \\
\hline 1118 & 3-methylbutanyl acetate & fruity & $\mathrm{ND}^{b}$ & $4.0 \pm 6.9$ \\
\hline 1128 & ethyl 2-methylpentanoate & fruity & $2.3 \pm 4.0$ & $74 \pm 13$ \\
\hline 1275 & octanal & sweet-green & $11 \pm 2.6$ & $11 \pm 2.6$ \\
\hline 1288 & 1-octen-3-one & metallic & $7.0 \pm 2.6$ & $5.0 \pm 2.0$ \\
\hline 1375 & (Z)-3-hexenol & green & ND & $6.0 \pm 5.2$ \\
\hline 1420 & ethyl octanoate & fruity & $4.7 \pm 2.3$ & $16 \pm 1.5$ \\
\hline 1511 & (E)-2-nonenal & sweet-green & $11 \pm 2.3$ & $13 \pm 2.5$ \\
\hline 1540 & linalool & floral & $4.0 \pm 1.0$ & $8.3 \pm 0.6$ \\
\hline 1609 & acetophenone & floral & $17 \pm 2.6$ & $12 \pm 5.0$ \\
\hline 1785 & (E)-beta-damascenone & sweet & ND & $6.7 \pm 6.1$ \\
\hline 2198 & methyl anthranilate & grape & $5.0 \pm 2.9$ & $110 \pm 21$ \\
\hline
\end{tabular}

${ }^{a}$ charm value : 有効数字を 2 桁とした 3 回試行による測定平均值土標準偏差.

${ }^{b} \mathrm{ND}$ : not detected. 


\section{文献}

1) Theodorou, E. and Paik, J. S., Effect of organic vapour interaction on permeation rate through polymer films. Packag. Technol. Sci. 5, 21-25 (1992).

2) Franz, R., Permeation of volatile organic compounds across polymer films-part I: development of a sensitive test method suitable for high-barrier packaging films at very low permeant vapour pressures. Packag. Technol. Sci. 6, 91-102 (1993).

3）松井利郎, 包装学基礎講座〈10〉, 「包装材料の吸脱着の科 学」, 第 1 版 (日本包装学会, 東京), p. 49 (2004).

4) Acree, T.E., Barnard, J. and Cunningham, D.G., A procedure for the sensory analysis of gas chromatographic effluents. Food Chem., 14, 273-286 (1984).

5) Deibler, K.D., Llesca, F.M., Lavin, E.H. and Acree, T.E., Calibration of gas chromatography inlet splitting for gas chromatography olfactometry dilution analysis. Flavour Fragr. J., 19, 518-521 (2004).

6) Akiyama, M., Murakami, K., Ikeda, M., Iwatsuki, K., Wada, A., Tokuno, K., Onishi, M., Iwabuchi, H. and Sagara, Y., Analysis of freshly brewed espresso using a retronasal aroma simulator and influence of milk addition. Food Sci. Technol. Res., 15 (3), 233-244 (2009).
7) Liu, J.R. and Gallander, J.F., Methyl anthranilate content of Ohio Concord grapes. J. Food Sci., 50, 280-282 (1985).

8）本石靖夫, 内層用エバール エンス, 29 (9), 65-72 (1990).

9) Zhou, Q., Guthrie, B. and Cadwallader, K.R., Development of a system for measurement of permeability of aroma compounds through multilayer polymer films by coupling dynamic vapour sorption with purge-and-trap/fast gas chromatography. Packag. Technol. Sci., 17, 175-185 (2004).

10) Campo, E., Ferreira, V., Escudero, A., Marques, J.C. and Cacho, J., Quantitative gas chromatography-olfactometry and chemical quantitative study of the aroma of four Madeira wines. Analytica Chimica Acta, 563, 180-187 (2006).

11) Liu, G. and Cadwallader, K.R., Aroma-impact components of "Carlos" muscadine grape juice. In "Flavor and health benefits of small fruits," eds. Qian, M.C. and Rimando, A.M., ACS symposium series 1035, (American Chemical Society (ACS), Washington, DC), pp. 63-77 (2010).

\section{引用 URL}

i) http://www.datuinc.com/charmware.html (2011. 10. 24) (平成 23 年 9 月 1 日受付, 平成 23 年 10 月 25 日受理) 